\title{
Impact of Industrial Effluents on Water Quality of Streams in Nakawa-Ntinda, Uganda
}

\author{
${ }^{1}$ PAUL WALAKIRA; ${ }^{2 *}$ JAMES OKOT-OKUMU
}

\author{
${ }^{1}$ National Bureau of Standards. P.O.Box, 6329, Kampala, Uganda. E-mail address: walakirap@yahoo.com \\ ${ }^{2}$ Makerere University Institute of Environment and Natural Resources (MUIENR), P.O.Box 7298, Kampala, Uganda.E-mail address: \\ jokotokumu@muienr.mak.ac.ug/jokotokumu@yahoo.com
}

\begin{abstract}
In Uganda industries generate large proportions of solid wastes and wastewater. The wastes are disposed into the environment untreated leading to pollution. This study was undertaken to examine selected physicochemical parameters of streams that receive effluents from different categories of industries in Nakawa Ntinda industrial area of Kampala. the stream water quality were $\mathrm{pH}(3.68-12.41 \mathrm{mg} / \mathrm{l})$, EC $\left(212-4633 \mu \mathrm{Scm}^{-1}\right)$, turbidity $(20.9-715.9 \mathrm{NTU})$, colour $(72-958 \mathrm{TCU})$, BOD $(16.4-325.5 \mathrm{mg} / \mathrm{l})$, COD $(39-135 \mathrm{mg} / \mathrm{l})$, TN $(0.45-$ $32.63 \mathrm{mg} / \mathrm{l}), \mathrm{TP}(0.078-1.674 \mathrm{mg} / \mathrm{l}), \mathrm{Na}(0.59-53.04 \mathrm{mg} / \mathrm{l}), \mathrm{Cl}(11.68-31.08 \mathrm{mg} / \mathrm{l}), \mathrm{Ca}(6.38-38.75 \mathrm{mg} / \mathrm{l}), \mathrm{Pb}(0.039$ $-0.256 \mathrm{mg} / \mathrm{l}), \mathrm{Cu}(0.015-0.52 \mathrm{mg} / \mathrm{l})$ and $\mathrm{Cd}$ (below detection limit). Food and beverage industries discharged effluents in noncompliance to Ugandan national regulations (BOD, COD, EC, Nitrogen, Turbidity and Colour), while chemical and pharmaceutical industries did not comply as regards heavy metals. All the industries did not have any wastewater treatment plant. This study reveals a scenario typical of most industries in developing nations where enforcement of environmental regulations are deficient. To avoid pollution Regulatory Authorities should closely monitor compliance by industries. @ JASEM
\end{abstract}

From the 1990s there has been rapid economic development in Uganda. One of the major economic development avenues in Uganda has been the manufacturing industries which have associated waste discharges that pollute the environment. Industrial pollution in the country is on the increase and is creating a high environmental risk. Pollution emitted from industries is one of the major factors contributing to the deterioration of water quality in Uganda. Dumping of various industrial waste products into water sources, and improper handling of industrial wastes, often result in polluting water sources. Such water pollution disturbs the balance of the ecosystem inside, resulting in the death of various animal and plant species present in the water. Pollution also reduces the potential of water as a resource for the various uses. This is because pollution causes the water to become unsuitable for various uses and also difficult and more expensive to treat to acceptable quality for use. Kampala is a home to many industries that include the sector of foods, beverages, paper, pharmaceuticals, chemical, textiles and iron and steels. The nature of emissions and effluents from industries are varied and industry specific. Phiri et al., (2005) noted that the careless disposal of industrial effluents and other wastes may contribute greatly to water pollution. Most of the water bodies in the areas of the developing world are the end points of effluents discharged from industries. Nakawa-Ntinda is one of the areas zoned for industrial development in Kampala. Industries at this site include factories of fish filleting, foods and beverages, plastics, chemical, pharmaceuticals, iron and steel and paints. The industrial area has streams traversing it that drain the area into a wetland (the Kinawataka wetlands) that links to Lake Victoria. Effluents from the Nakawa-Ntinda industries are discharged into these streams untreated and is a threat to the integrity of these streams and eventually Lake Victoria. Downstream these streams, the water is used for washing vehicles, washing clothes, irrigation of vegetables, drinking (wildlife) and recreation by children. A study (LVEMP, 2002) on the management of industrial and municipal effluents in the Lake Victoria basin in Uganda indicated that most factories do not have effluent treatment plants and even where they existed most of them were poorly designed and constructed. Therefore of those that have effluent treatment plants, only few were achieving effluent discharge standards. Muwanga and Barifaijo (2006) demonstrated industrial effluents as one of the main pollution in the Lake Victoria basin in Uganda. This is evident in studies that indicate that Lake Victoria has suffered increasing levels of pollution in recent years (COWI, 2002; NWSC, 1998 $\& 2000)$. This is threat to both the bio-diversity of the lake and the continued sustainable use of the lake resources. It is therefore important to assess pollution from the industries so as to understand their threats to the environment and design appropriate mitigation measures. This study therefore assessed the quality of effluents from the different industries that discharge into the Nakawa-Ntinda streams and channels and water quality status of the receiving streams. It is hoped that the results of this study will assist the relevant industries and authorities in designing appropriate mitigation measures to ensure that the water quality in the streams is protected.

\section{MATERIALS AND METHODS}

The study site is the Nakawa-Ntinda industrial area that is traversed by the Ntinda, Kyambogo and Mukabya streams. The layout of the study area and the sample collection sites are shown in Fig. 1. 
Effluent from five industries and water from the streams were sampled for physico-chemical analysis. The five industries $t$ included a fish filleting factory; food and juice and confectionery factory (biscuit, fruit juice, sweets, and mineral water); foam mattress factory; a pharmaceutical factory and a beverage factory (bottled soft drinks).

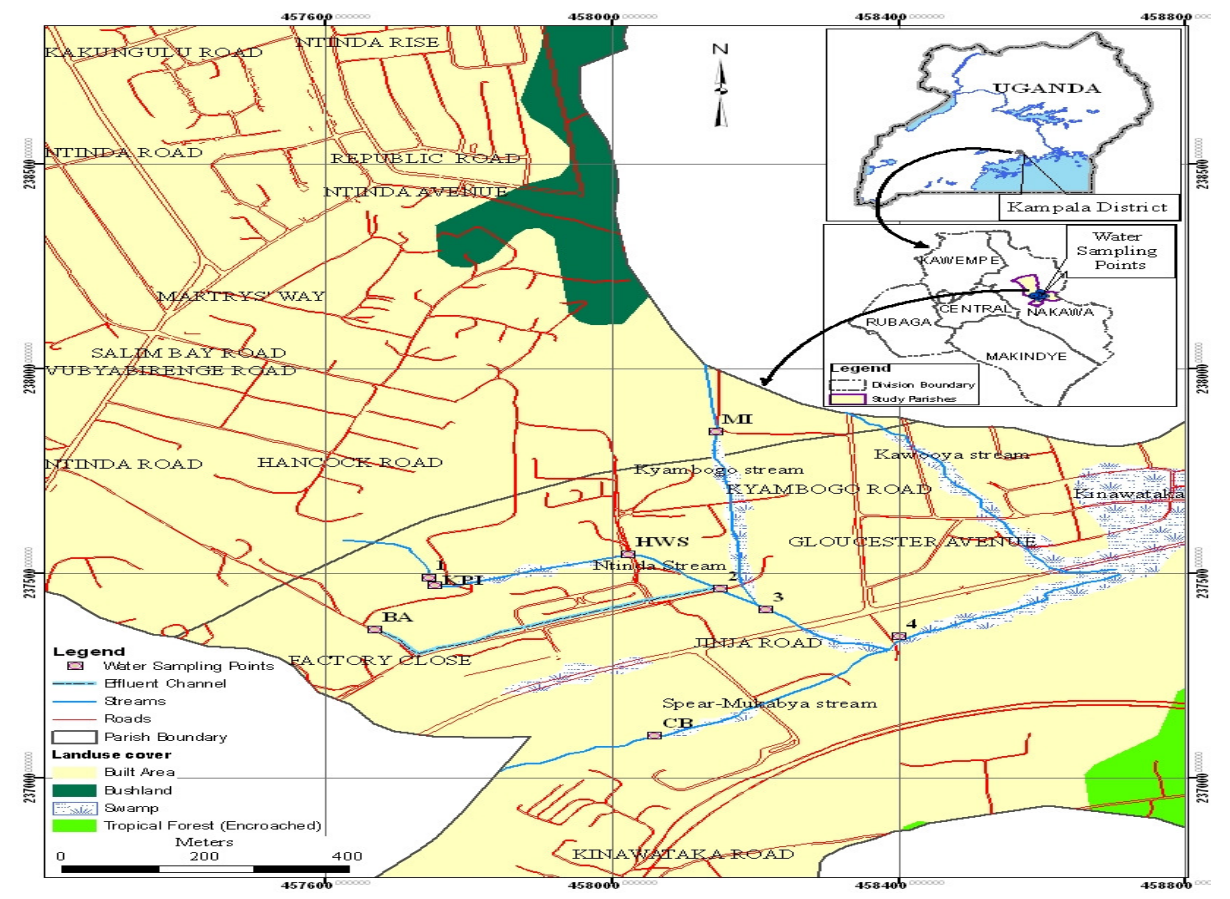

Fig 1: Map of the study area showing the sampling sites (BA, CB, HWS, KPI, 1, 2, 3, 4)

Water samples were collected at locations indicated in Figure 1 (BA, CB, HWS, KPI, MI, 1, 2, 3 \& 4) and handled according to standard methods (APHA, 1998). Conductivity and $\mathrm{pH}$ were measured in situ using field meters (Mettler Toledo 320 and MC 226 respectively) with appropriate probes according to the manufacturer's instruction.

Water samples were collected in duplicate in the morning and afternoon for a period two months (March and April, 2010) at sites 1, 2, 3 and 4 along the stream. Site 1 is upstream of Ntinda stream, before the industrial waste discharge points and is considered as control sampling site. Site 2 is close to a point discharge from the food and beverage factory on the Ntinda stream that receives effluent from the fish processing factory while site 3 is at the confluence of Kyambogo (foam industry) and Ntinda streams (Fish, food \& beverage). While sampling site 4 receives a combine flow from the streams receiving effluents from all the industries.

SAMPLE ANALYSIS: All samples for laboratory analysis $\left(\mathrm{Na}^{+}, \mathrm{K}^{+}, \mathrm{Cl},{ }^{-1} \mathrm{Ca}^{2+}, \mathrm{Pb}^{2+}, \mathrm{Cd}^{2+}\right.$ and $\mathrm{Cu}^{2+}$ ,COD, BOD, turbidity, colour, TP, and TN ) were determined according to Standard Methods for Examination of Water and Waste water (APHA, 1998). Turbidity levels were measured in Nephelometric units (NTUs) using the HACH 2100A turbidity meter. Colour was determined using a Spectrophotometer (DR 20800 model). Total Nitrogen was determined using DR4000 spetrophotometer at $543 \mathrm{~nm}$. Total Phosphorus was determined calorimetrically method using visible spectrophotometer (model DR 3800- HACH). Sodium was determined using a flame photometer (Model CORNING M410). Calcium, lead, copper and cadmium were determined using Atomic Absorption Spectrometer (model AA6800SHIMADZU).

DATA ANALYSIS: MS Excel and Gen Stat were used to analyse data. Analysis of variance (ANOVA) was used to determine the significant difference of concentrations for various parameters. Differences in concentration levels obtained for a given parameter along sampling locations were considered significant if calculated $\mathrm{P}$-values were $<0.05$. Correlation was applied to test the relationship between various parameters along sampling site. 


\section{RESULTS AND DISCUSSION}

Results of the analysis of water samples from the stream revealed trends displayed in Figures 2 to 9. $\mathrm{pH}$ values at location 1 upstream, KPI, BA, location 2, HWS, MI, location $3, \mathrm{CB}$ and location 4 downstream were $6.73 \pm 0.1,6.73 \pm 0.2, \quad 3.68 \pm 0.1$, $3.91 \pm 0.1,6.87 \pm 0.6,6.78 \pm 0.4, \quad 8.47 \pm 0.8, \quad 12.41 \pm 4.6$ and $5.07 \pm 0.1$ respectively. $\mathrm{pH}$ varied significantly $(\mathrm{p}=0.02$, ANOVA) among sampling locations and locations BA, 2 and 4 were acidic and outside the accepted national discharge standards (GoU, 1999). The low pH at BA and 2 can be attributed to acidic fruit juice ingredients and fermentation by-products from the food and fruit juice factories, while location 4 apart from being in a wetland (acidic water) has many human activities nearby and also receives acidic water along the stream from BA and 2. Water at location 4 is being used for different purposes by the population even though it is unsuitable for use at the recorded $\mathrm{pH}$. According to Phiri et al., (2005) low $\mathrm{pH}$ levels in effluent from factories are attributed to the raw materials such enzymes, lactic acid, benzoic acid and yeast that are commonly used. Locations CB and 3 exhibited alkaline $\mathrm{pH}$ above the national standards which is attributed to the cleaning agent (caustic soda- $\mathrm{NaOH}$ ) used at $\mathrm{CB}$ and discharge from a coffee factory to location 3 . The recorded influence on stream $\mathrm{pH}$ by industrial effluent is similar to previous studies (Muwanga \& Barifaijo, 2006; Oladele et al., 2011). According to Michnowicz and Weaks (1984) low pH $(<4.0)$ increases the toxicity of heavy metals (e.g. As, $\mathrm{Cr}, \mathrm{Cu}, \mathrm{Zn}$ ). High $\mathrm{pH}$ values increase the toxicity of ammonia to aquatic organisms. The UNBS 1994 and WHO permissible $\mathrm{pH}$ levels for drinking water is $6.0-8.0$ (UNBS 1994; WHO, 2008).

Table 1. Potential influence of pollution sources on water quality of the streams\#

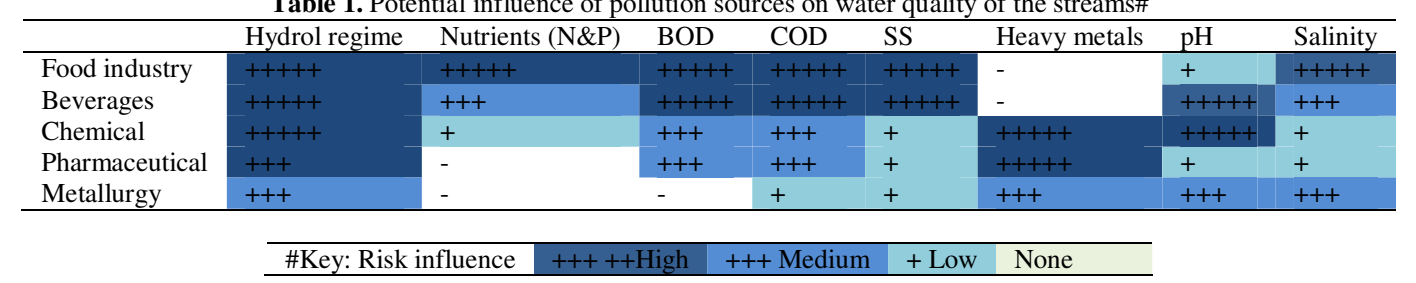

Figure 3 shows the trends of Electrical conductivity (EC) at the different locations in the streams. EC $\left(\mu \mathrm{Scm}^{-1}\right)$ recorded at location 1 upstream, KPI, BA, location 2, HWS, MI, location 3, CB and location 4 downstream were $280 \pm 58.2,337 \pm 74.1,4633 \pm 154.4$, $373 \pm 88.6, \quad 1929 \pm 471.7, \quad 212 \pm 51.1, \quad 341 \pm 58.3, \quad 984$ \pm 132.8 and $362 \pm 105.8$ respectively. The upstream EC value indicates some influence from human activities in the catchment. The food and beverage industries discharge effluents with high EC because of the combination of cleaning agents (detergents and $\mathrm{NaOH}$ ) and additives for food and beverages (e.g. sodium benzoate- $\mathrm{C}_{6} \mathrm{H}_{5} \mathrm{COONa}$ and common salt $\mathrm{NaCl}$ ) that get into the cleaning water stream. All the EC recorded in the stream are above the surface water background levels $(90-130 \mu \mathrm{Scm}-1)$ in the study area which is an indication of high TDS from the industrial effluents. The strong correlation $\left(\mathrm{r}^{2}=0.92\right)$ between EC and BOD compared with COD $\left(\mathrm{r}^{2}=0.05\right)$ indicate predominance of ionised products of organic decomposition origin (e.g. fish flesh, blood, food waste) that get into the effluents from the industries. This is exemplified further by the strong correlation $\left(\mathrm{r}^{2}=0.6\right)$ between BOD and turbidity.

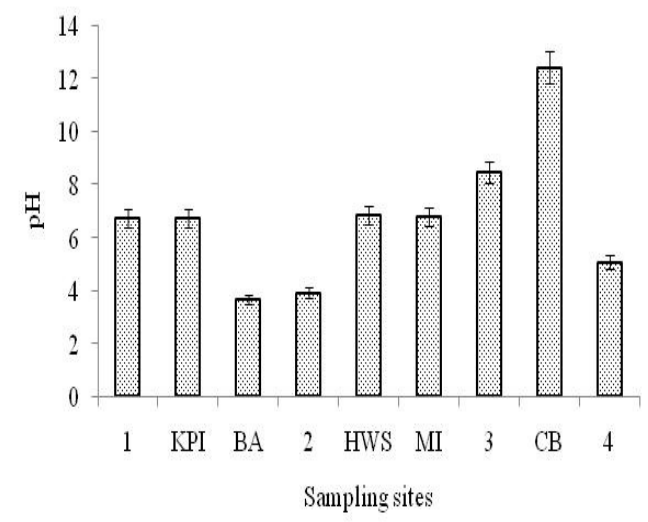

Fig.2. $\mathrm{pH}$ trend along the streams. GOU standards = 6-8

Turbidity (NTU) recorded at location 1 upstream, KPI, BA, location 2, HWS, MI, location 3, CB and location 4 downstream were $29.7 \pm 0.9,20.9 \pm 0.2$, $715.9 \pm 9.3,39.1 \pm 0.8,615.7 \pm 94.3,30.7 \pm 0.5,38.3 \pm 0.1$, $492.6 \pm 109.5$ and $551.7 \pm 118.1$ respectively. Similar to the EC situation it is the food industries that discharge effluents of high turbidity affecting the stream water quality within the industrial zone and downstream as shown by the value at location 4 being higher that the national standards of 300 NTU (Figure 4). 


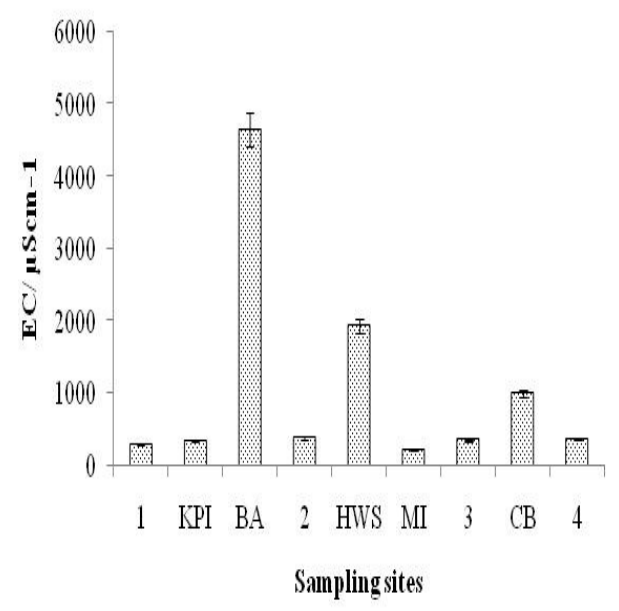

Fig.3. Electrical conductivity trend along the streams.

Muwanga and Barifaijo (2006) also recorded such high turbidity values in effluents from food industries. The high value of turbidity from the industries can be attributed to decomposing organic natter in the effluents. This is evident in the strong correlation observed between Turbidity, Biochemical Oxygen Demand and Total Nitrogen of the stream water (Table 1). Colour had a similar trend to turbidity in that it was highest at the food industries (Figure 4). Colour (TCU) recorded at location 1 upstream, KPI, BA, location 2, HWS, MI, location 3, $\mathrm{CB}$ and location 4 downstream were $72 \pm 0.2 .1,101$ $\pm 4.3,499 \pm 51.2,2958 \pm 86.5,302 \pm 5.9,123 \pm 2.7,113$ $\pm 2.13,777 \pm 59.9$ and $319 \pm 5.98$ respectively The food industries were not in compliance with the national standards of effluents as regards EC, turbidly and colour. The colours in the effluents from the food industries are caused by release the decomposing organic matter and food colouring chemicals especially from the confectionery industry. This is evident in location 2 that is close to effluent discharge point of a confectionery factory. Colours and turbidity in water interfere with sunlight penetration and affects photosynthesis. They also affect aquatic organism respiration and expose them to risks from prey. There was also a strong correlation $\left(r^{2}=0.7\right)$ between colour and Total Phosphorus (Table 2) which can be attributed to the use of coloured detergents in the industries.

Figure 5 shows the trend of Biochemical oxygen demand (BOD) along the streams. BOD (mg/l) recorded at location 1 upstream, KPI, BA, location 2, HWS, MI, location 3, CB and location 4 downstream were $46.2 \pm 2.9,32.6 \pm 7.6, \quad 325.5 \pm 40.3,35.2 \pm 1.2$, $180.6 \pm 24.1, \quad 16.4 \pm 0.5, \quad 17.7 \pm 1.8, \quad 35.2 \pm 1.4$ and
93.2 \pm 58 respectively. These BOD values are much higher than the normal background level of $2-3 \mathrm{mg} / \mathrm{l}$. Effluents from food industries had significantly higher BOD $(p=0.002$, ANOVA $)$ compared to effluents from other industries and the stream locations. This is due to discharge of organic matter (e.g. fish flesh, blood, flour, food fragments) from processing line into wastewaters from the food industries. Effluents from the food industries were in noncompliance to national discharge standards, while the other industries were in compliance. LVEMP (2002) established that pollution loading (kg/day) from industry due to BOD accounted for $13 \%$ of the total estimated pollution loading into Lake Victoria after passing through wetlands and other natural purification systems. The lower levels of BOD at locations 2 , and 3 can be attributed to dilution effect and natural purification mechanisms such as respiratory breakdown, and biological and physical uptakes in the aquatic ecosystem. The strong correlation $\left(\mathrm{r}^{2}=0.58\right)$ between BOD and Total Nitrogen (Table 2) indicates that the biodegradable organic matter is nitrogen rich that implicates the food processing factories. Location 4 downstream depicted increased BOD levels in noncompliance with national discharge standards which may be attributed to cumulative effects from activities at this site and upstream.

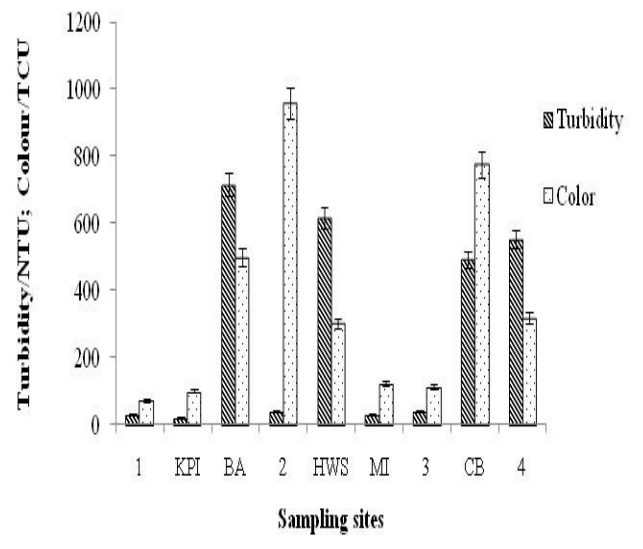

Fig.4. Turbidity and colour trends along the streams. GOU standard $=300$

Chemical oxygen demand (COD) displayed trends similar to BOD except at location 2. COD (mg/l) recorded at location 1 upstream, KPI, BA, location 2, HWS, MI, location 3, CB and location 4 downstream were $76 \pm 14.2,71 \pm 12.3,1105 \pm 412.8,2104 \pm 218.2$, $1351 \pm 321.1,39 \pm 1.2,35 \pm 7.1,94 \pm 4.3$ and $278 \pm 5.2$ respectively (Figure 6). 


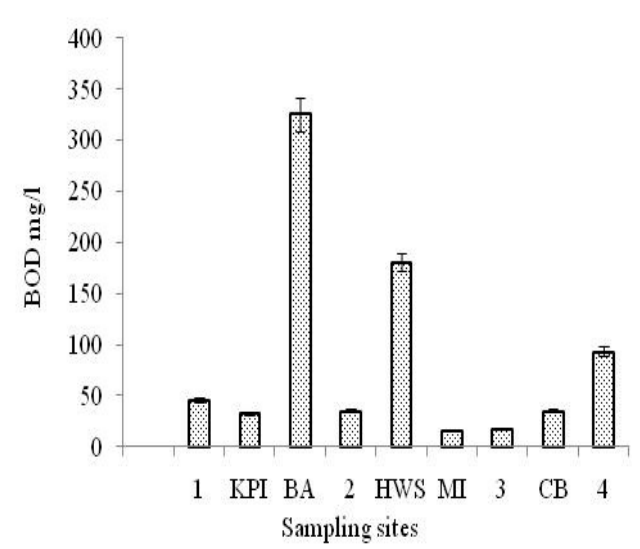

Fig.5. Trend of BOD along the streams. GOU Standards $=50 \mathrm{mg} / \mathrm{l}$

The food industries again were in non compliance with the national standards for effluent discharge. COD varied significantly ( $p=0.006$, ANOVA) which can be attributed to the different oxidising agents unique to the different industries and those found naturally in the environment. The peak at location 2 can be attributed build-up of organic and inorganic pollution loads from the industries similar to the other reported cases of industrial discharges (Kayima et al., 2008; Muwanga \& Barifaijo, 2006; Oladele et al., 2011). A slight build up of COD is registered downstream at location 4 for similar reasons as for BOD.

The trend of nitrogen in the streams is displayed by Figure 7. Total Nitrogen $(\mathrm{TN}-\mathrm{mg} / \mathrm{l})$ recorded at location 1 upstream, KPI, BA, location 2, HWS, MI, location 3, $\mathrm{CB}$ and location 4 downstream were $0.45 \pm 0.2,1.92 \pm 0.2,25.67 \pm 1.6,10.7 \pm 1.3,32.63 \pm 4.1$, $6.52 \pm 1.19,2.7 \pm 2.1, \quad 5.13 \pm 0.5$ and $13.75 \pm 1.6$ respectively. Total nitrogen varied significantly among the sampling locations $(\mathrm{p}=0.001$, ANOVA) and were higher and in noncompliance to the national standards at all food industries and downstream of the industries. This is attributed to the decomposition of organic matter from the food industries that release nitrogen and this is exemplified by the strong correlation between BOD and TN. The high TN values at location 3 are attributed to a solid waste dump site nearby and defective leaking sewers that discharge into the stream. The chemical and pharmaceutical industries were in compliance with the standards (GoU, 1999). Major routes of entry of nitrogen into water bodies are municipal and industrial wastewater, private sewage disposal systems, decaying plant debris. According to LVEMP (2002) industries accounted for $10 \%$ of the pollution loading (kg/day) due to $\mathrm{TN}$ into Lake Victoria after passing through wetlands and other natural purification systems.

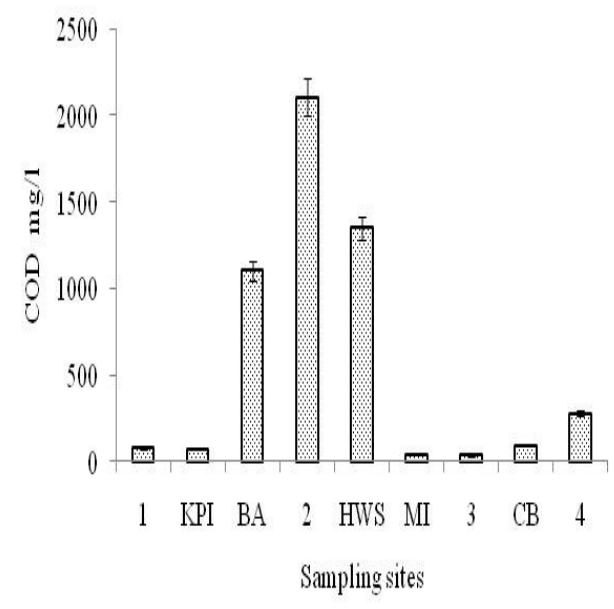

Fig.6. Trend of COD along the streams. GOU Standards $=100 \mathrm{mg} / \mathrm{l}$

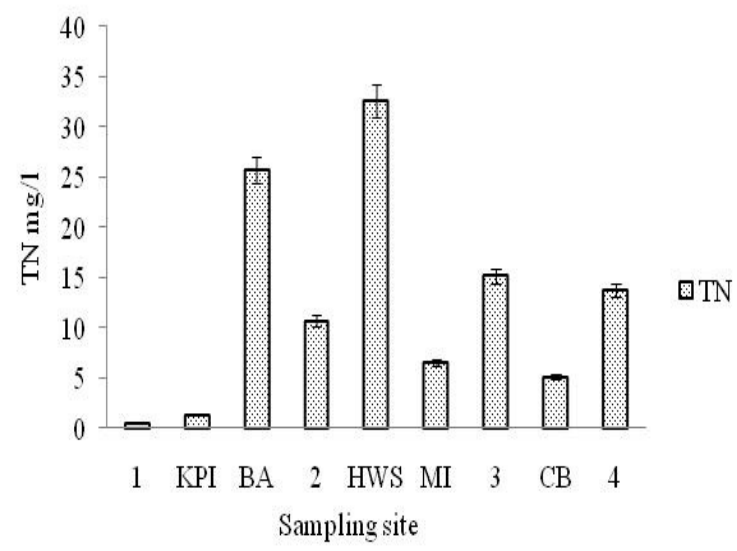

Fig.7. Total Nitrogen trend along the streams. GOU Standard $=10 \mathrm{mg} / \mathrm{l}$

Total phosphorus (TP- mg/l) trends are displayed in Figure 8. TP recorded at location 1 upstream, KPI, BA, location 2, HWS, MI, location 3, CB and location 4 downstream were $0.078 \pm 0.01,0.144 \pm 0.2$, $1.674 \pm 0.2, \quad 1.293 \pm 0.3, \quad 0.394 \pm 0.1, \quad 0.345 \pm 0.2$, $0.424 \pm 0.2,1.629 \pm 1.3$ and $0.251 \pm 1.7$ respectively. The phosphorus seems mainly from non-food sources such as detergents and other inorganic sources. This is confirmed by the strong correlation to colour (about $\left.r^{2}=0.7\right)$ compared to BOD $\left(r^{2}=0.18\right)$. Total phosphorus varied significantly $(\mathrm{p}=0.003$, ANOVA) among sampling locations. All industries were 
complying with the national standards for the discharge of effluents. Food industry effluents exhibited the highest TP values and this can be attributed to the heavy use of detergents for cleaning in this industries. The cleaning process generates large volumes of wastewater that is discharged into the streams.

In general Location 4 indicated the dilution effect of the stream water on some of the effluents that may be due to physical or due to biological uptakes in the streams. However in some cases (BOD, COD, TN) the effluent contents were still at unacceptable levels and this is attributed to cumulative impacts of human activities downstream that offset the stream physical, chemical and biological removal of these pollutant. Nitrogen, phosphorus, or both may cause increased aquatic productivity leading to eutrophication water bodies such as lakes and (Fatoki et al., 2001; Rast \& Thornton, 1996).

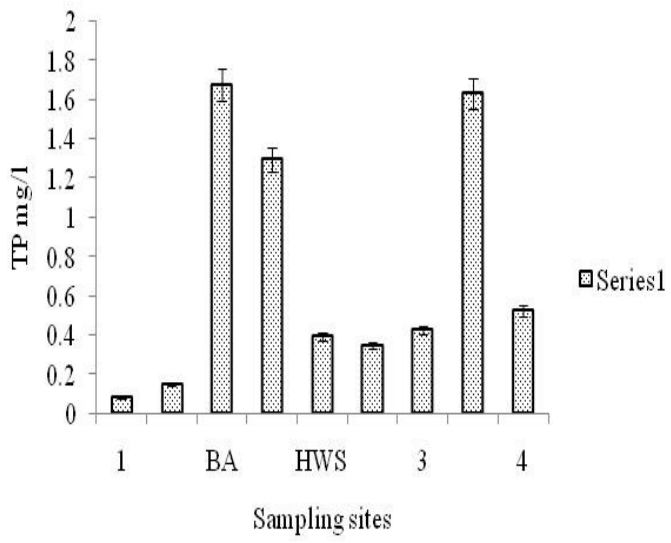

Fig .8. Total Phosphorus trend along the streams. GOU Standards $=10 \mathrm{mg} / \mathrm{l}$

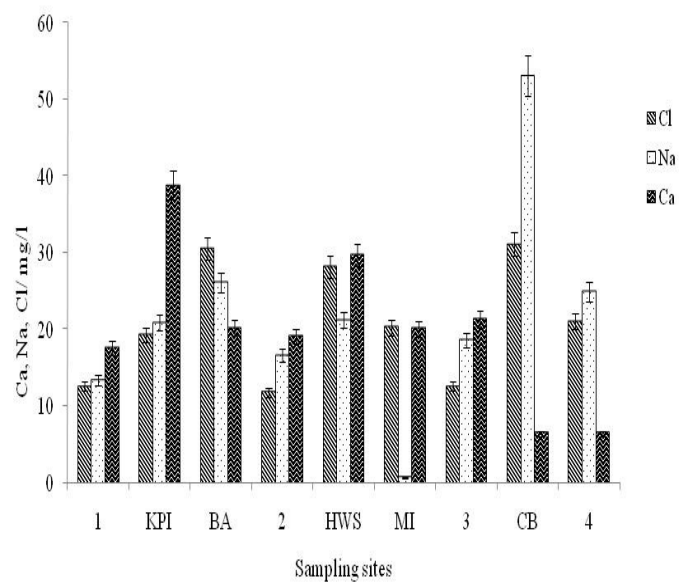

Fig.9. Calcium, sodium and chloride trends along the streams
The analysed cations and anions in the stream were $\mathrm{Ca}^{++}, \mathrm{Na}^{+}$and $\mathrm{Cl}^{-}$. Figure 9 shows trends of these elements along the streams. Calcium ranged from $17.49 \pm 1.86$ to $38.75 \pm 7.41 \mathrm{mg} / \mathrm{l}$, sodium ranged from $0.59 \pm 0.27$ to $53.04 \pm 1.74 \mathrm{mg} / \mathrm{l}$ and chloride ranged from $11.68 \pm 0.14$ to $31.08 \pm 1.48 \mathrm{mg} / \mathrm{l}$. These elements varied significantly $(p=0.001$, ANOVA) among sampling locations and the levels obtained were within the national maximum permissible limits. Figure 11 shows the trend of heavy metals (lead, copper and cadmium) along the stream. Lead concentrations $(\mathrm{mg} / \mathrm{l})$ recorded at location 1 upstream, KPI, BA, location 2, HWS, MI, location 3, $\mathrm{CB}$ and location 4 downstream were $0.05 \pm 0.01$, $0.256 \pm 0.1, \quad 0.039 \pm 0.01, \quad 0.051 \pm 0.01, \quad 0.048 \pm 0.01$, $0.074 \pm 0.01,0.112 \pm 0.02,0.082 \pm 0.01$ and $0.154 \pm 0.02$ respectively. Non compliant levels to GoU 1999 regulations were at the effluent of the pharmaceutical industry and downstream that can be attributed to some chemicals that are used in manufacture of drugs that may contain lead-organo compounds as observed by Muwanga \& Barifaijo (2006). Downstream lead concentration can be attributed to the high concentration of vehicles in this zone due to the numerous car sale depots and vehicle parking lots that discharge (leaks) fuel and contaminated engine oil into the environment. Though of low phytotoxicity lead may become mobile at lower $\mathrm{pH}$ and enter the food chain from the numerous agricultural activities that use the stream water posing health risks to consumers of the agricultural produce (Nabulo et al., 2008). Copper was below maximum permissible discharge limits at all sampling locations except MI the foam mattress site. The copper seems to be originating from a metal fabrication site and not the foam mattress industry. Copper concentration in the stream varied significantly $(\mathrm{p}<0.05$, ANOVA) along sampling the stream. Although copper toxicity in humans is rare, aquatic organisms are potentially at risk from exposures (Adriano, 2001). As observed by Muwanga \& Barifaijo (2006), the low levels of copper observed along the stream are attributed to the natural purification processes within the streams. Cadmium was not detected at all sampling locations in the streams. Muwanga and Barifaijo (2006) however detected very low levels of Cadmium in Kinawata streams and this may be due the difference in sample locations. Cadmium is a non-essential element and it is both bioavailable and toxic. It interferes with metabolic processes in plants and can bioaccumulate in aquatic organisms and enters the food chain (Adriano, 2001). Plants consumed by people as food are known to accumulate heavy metals by uptake to levels that present risks to consumers (Nabulo et al., Segura-Muñoz, et al., 
2006) and sometimes the plants themselves (SeguraMuñoz, et al., 2006).

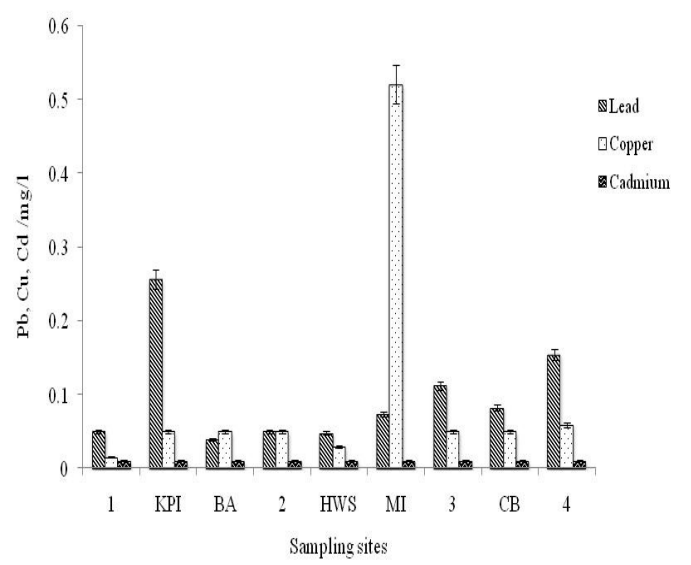

Fig. 10. $\mathrm{Pb}, \mathrm{Cu}$ and $\mathrm{Cd}$ trends along the streams. GOU Standards $=0.1 \mathrm{mg} / \mathrm{l}$

Analysis of the pollution potentail from all the investigated category of industries is presented in Table 2. This clealy illustrates the impact of the different category of industries.with respect to the different pollutants. The hydrological regime is affected by most industries because odf the use of large quantities of water in production and cleaning. This is because of abstraction of large volumes of water and discharge of large volumes of effluents into the environment. It has been demonstrated that all the industries in Ntinda-Nakawa industrial zones are polluting the environment even though most of the locations within the receiving streams were within acceptable effluent quality limits. Of concern were the high BOD, COD, colour, $\mathrm{pH}, \mathrm{TN}$ and turbidity from food industries and the heavy metals lead and copper from pharmaceutical industry and metalworks. Based on the determined parameters the stream water is not suitable for human consumption and vegetable irrigation. Variation of $\mathrm{pH}$ and heavy metals concentration were caused by industrial effluents and other human activities in the stream catchment. Much precaution should be taken on the use of water from the streams. Vegetable irrigation is one major use of the stream water that poses risks to people. It is therefore important to investigate uptake of heavy metals by irrigated vegetables in the stream catchment. All the industries do not treat the effluents generated before discharge into the streams. The continued discharge of un-treated effluents into the streams may result in severe accumulation of the contaminants. Most of these industries were set up without carrying out Environmental Impact Assessment (EIA) and also most do not carry out the mandatory periodical Environmental audits (EA). These industries consequently do not have any clear environmental management policy and environmental management plan. It is imperative that all the industries that generate wastewater that exceed national standards should treat the effluents before discharging into the environment. These industries should undego regular environmental audits as required by law (Goverment of Uganda , 2006). None of the industries in the Ntinda-Nakawa area is practicing Cleaner Production (CP). These industries should seek help from the NatIonal Cleaner Production Centre that is also located in this area (Ntinda-Nakawa) to implement $\mathrm{CP}$ and solve the pollution problems so as to make propfits in a 'clean' manner.

Acknowledgement: We extend our sicere gratitude to the Uganda National Bureau of Standards for all the assistance offered during that study that included the use of their equipment and laboratory for sample analysis .

\section{REFERENCES}

Adriano, D C (2001). Trace elements in terrestrial environments: Biochemistry, bioavailability and risks of metals. Springer p867.

APHA, (1998). Standard Methods for Examination of Water and Waste water. American Public Health Association. Washington.

Chennakrishnan C, Stephren A, Manju T and Raveen $R$ (2008). Water Quality status of three vulnerable freshwater Lakes of Suburban Chennai, India. Indian J Environ \& Ecoplan 15(3):591-596.

COWI Consulting Engineers and Planners (2002). Integrated water quality/limnology study for Lake Victoria. Lake Victoria Environmental Management Project, Draft Final Report.

Fakayode, S O (2005). Impact of industrial effluents on water quality of the receiving Alaro River in Ibadan, Nigeria, Ajeam-Ragee, 10:1-13.

Fatoki, O S; Muyima N Y O; Lujiza N (2001). Situational Analysis of Water in the Umtata River catchment. Water SA 27(4):467-474.

Government of Uganda (GoU) (2006). The National Environment Audit regulations. The Uganda Gazette No. 14 Vol XCVIX.

Government of Uganda (GoU) (1999). The Uganda National Environment (Standards for Discharge of effluent into water or land) Regulations. The 
Impact of Industrial Effluents.....

Uganda Gazette No. 7Vol XCII.

Kayima J; Kyakula M; Komakech W; Echimu SP (2008). A study of the degree of pollution in Nakivubo Channel, Kampala, Uganda. J. Appl. Sci. Environ. Manage 12(2): 93 - 98.

Lake Victoria Environmental Management Program (LVEMP) (2002). Water quality management and sustainability: the experience of Lake Victoria Environmental Management Project.

Michnowicz, C J. and Weaks T E (1984). Effects of $\mathrm{pH}$ on toxicity of $\mathrm{As}, \mathrm{Cr}, \mathrm{Cu}, \mathrm{Ni}$ and $\mathrm{Zn}$ to Selenastrum capricornutum Printz. Hdrobiol 118: 299 -305.

Muwanga, A; Barifaijo, E (2006). Impact of industrial activities on heavy metal loading and their physico-chemical effects on wetlands of the Lake Victoria basin (Uganda). AJST 7 ( 1): 5163.

National Water and Sewerage Corporation (NWSC) (1998). New Gaba 2 Water Treatment Plant: Facts and Figures at a Glance (Unpublished).

National Water and Sewerage Corporation (NWSC) (2000). Annual Water Quality Monitoring Reports, (1998/1999 and 1999/2000).

Nabulo, G; Oryem Origa, H; Nasinyama, G W and; Cole, D (2008). Assessment of $\mathrm{Zn}, \mathrm{Cu}, \mathrm{Pb}$ and $\mathrm{Ni}$ contamination in wetland soils and plants in the Lake Victoria basin. Int. J. Environ. Sci. Tech., 5(1): 65-74.
Oladele, O; Adegbenro, P D; Adewole, M G (2011). The impact of industries on surface water quality of River Ona and Riva Alaro in Oluyole Industrial Estate Ibadan, Nigeria. African Journal of Biotechnology 10 (4): 696-702.

Phiri, O; Mumba, P; Moyo, B H Z; and Kadewa, W (2005). Assessment of the impact of industrial effluents on water quality of receiving rivers in urban areas of Malawi. Int. J. Environ Sci Tech 2(3): 237-244.

Rast W and Thornton J A (1996). Trends in eutrophication research and control. Hydobiol Processes (10): 259-313.

Segura-Muñoz, S I; da Silva Olivera, A; Nikaido, M; Trevilato, T M B; Bocio, A; Takayanagui, A M M; Domingo, J L (2006). Metal Levels in Sugar Cane (Saccharum spp) samples from an area under the influence of municipal landfill and a medical waste treatment in Brazil. Environ Int (32): 52-57.

Uganda National Bureau of Standards (UNBS) (1994). Standard Specification for Drinking (Potable) Water, First Edition, Kampala. 6 pp.

World Health Organization (WHO) (2008). Guidelines for Drinking-Water Quality [electronic source]: incorporation $1^{\text {st }}$ and $2^{\text {nd }}$ addenda, Vol.1. $3^{\text {rd }}$ ed. 